\title{
Chapter 7 \\ Pest Management in Grain Legumes and Climate Change
}

\author{
H.C. Sharma, C.P. Srivastava, C. Durairaj, and C.L.L. Gowda
}

\subsection{Introduction}

Grain legumes such as chickpea (Cicer arietinum L.), pigeonpea [Cajanus cajan (L.) Millsp.], cowpea (Vigna unguiculata Walp.), field pea (Pisum sativum L.), lentil (Lens culinaris Medic.), greengram [Vigna radiata (L.) Wilczek], blackgram [Vigna mungo (L.) Hepper], bean (Phaseolus vulgaris L.), faba bean (Vicia faba L.), and grasspea (Lathyrus sativus L.) are the principal source of dietary protein among vegetarians, and are an integral part of daily diet in several forms worldwide. Grain legumes are cultivated on 23 million hectares, accounting for over $18 \%$ of the total arable area, but only $8 \%$ of the total grain production. There is a large disparity between yields of cereals and legumes. The global pulse production in 2006 was over 59.47 million tons over an area of 71.21 million ha, with an average productivity of $835 \mathrm{~kg} \mathrm{ha}^{-1}$ (FAO, 2008). In India, the total pulse production in 2006 was 13.14 million tons on an area of 22.25 million ha, with an average productivity of $591 \mathrm{~kg} \mathrm{ha}^{-1}$. Worldwide, chickpea and pigeonpea are the two major food legumes, cultivated on an area of 10.38 and 4.57 million ha, respectively. The total production being 8.57 and 3.29 million tons, with an average productivity of 826 and $720 \mathrm{~kg} \mathrm{ha}^{-1}$, respectively. In addition to being a source of dietary proteins and income to resource poor farmers in the semi-arid tropics, food legumes play an important role in sustainable crop production. They are an important component of cropping systems to maintain soil health because of their ability to fix atmospheric nitrogen, extract water and nutrients from the deeper layers of the soil, and add organic matter into the soil through leaf drop. However, food legumes are mainly grown under rainfed conditions and the productivity levels are quite low mainly because of severe losses due to insect pests and diseases.

H.C. Sharma $(\bowtie)$

International Crops Research Institute for the Semi-Arid Tropics (ICRISAT), Patancheru 502324, Andhra Pradesh, India

e-mail: H.sharma@cgiar.org 


\subsection{Climate Change and Its Influence on Production of Grain Legumes}

Despite the availability of overwhelming evidence in support of climate change, uncertainty prevails over the exact nature and consequences of climate change especially at the local level, making it difficult to plan and develop appropriate adaptation strategies, programs, and technologies. Global level simulations using climate models provide various scenarios with high levels of confidence, but these predictions become less clear as to the magnitude and timing of the changes at sub-regional, national and local levels. Difficulties remain in reliably simulating and attributing observed temperature changes at smaller scales (IPCC, 2007). However, it is widely recognized that the increased heat stress, shift in monsoons, and drier soils pose much greater threat to production of grain legumes in the tropics than the temperate regions (Rosenzweig and Liverman, 1992). With most developing countries located in the tropics and most of them being heavily dependent on agriculture for food and income, the relatively poor countries with limited resources face the costly and formidable task of adapting to climate change. Despite the many assumptions and uncertainties associated with the crop and climate models, the analysis has indicated that South Asia and Southern Africa are the two regions that are particularly sensitive to the impacts of climate change, and without sufficient adaptation measures, are likely to suffer from negative impacts of climate change, and such effects would be more severe in case of grain legumes which are more sensitive to climate change than the robust tropical cereals such as sorghum and pearl millet. Unhindered climate change has the potential to negatively impact crop production because of shortening of the cropping season, and increased severity of drought and a pest spectrum.

\subsection{Insect Pest Problems in Grain Legumes and the Likely Influence of Climate Change on Distribution and Severity of Damage by Insect Pests}

Grain legumes, being a rich source of proteins, are damaged by a large number of insect species, both under field conditions and in storage (Clement et al., 2000; Sharma et al., 2003) (Table 7.1). Amongst the many insect pests damaging food legumes, the pod borers, Helicoverpa armigera (Hubner) and H. punctigera (Wallengren) are the most devastating pests of chickpea and pigeonpea in Asia, Africa, and Australia. They also damage other food legumes to varying degrees in these regions (Sharma, 2001). The spotted pod borer, Maruca vitrata (Geyer), is a major pest of cowpea and pigeonpea, but also damages other food legumes, except chickpea and lentil (Sharma et al., 1999). The pod fly, Melanagromyza obtusa Malloch and pod wasp, Tanaostigmodes cajaninae La Sale cause extensive damage to pigeonpea in India. The leaf miner, Liriomyza cicerina (Rondani) is an important pest of chickpea in West Asia and North Africa (Weigand et al., 1994), and 


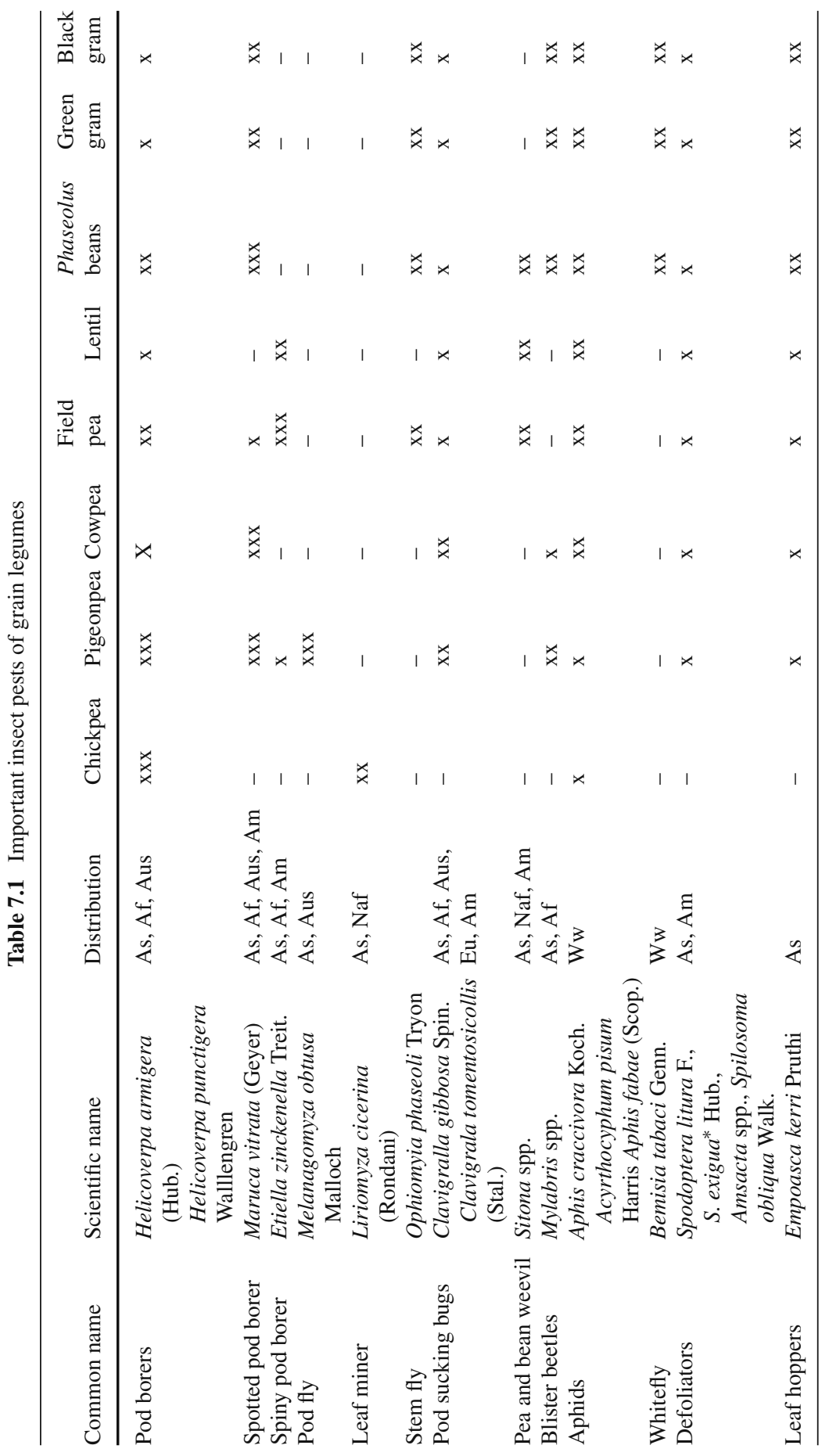




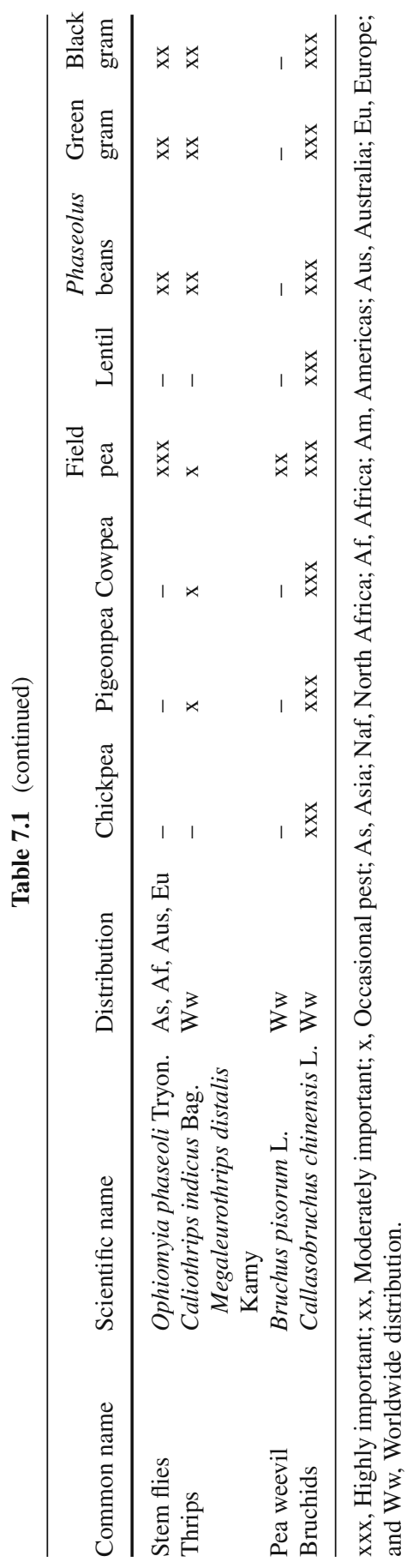


has also been reported from North India (Naresh and Malik, 1986). The spiny pod borer, Etiella zinckenella Triet. is a major pest of pigeonpea, field pea, and lentil. The aphid, Aphis craccivora Koch infests all the food legumes, but is a major pest of cowpea, field pea, faba bean, and Phaseolus beans, while Aphis fabae (Scop.) is a major pest of faba bean and Phaseolus beans. The pea aphid, Acyrthosiphon pisum Harris is a major pest of field pea worldwide. The cotton whitefly, Bemisia tabaci Genn. infests all the crops, except chickpea, but is an important pests of Phaseolus spp., black gram, and green gram. The defoliators, Spodoptera litura (Fab.) in Asia and S. exigua Hubner in Asia and North America, are occasional pests. The Bihar hairy caterpillar, Spilosoma obliqua Walk. is a major pest of green gram and black gram in North India, while the red hairy caterpillars, Amsacta spp. damage the rainy season pulses in South central India. Leafhoppers, Empoasca spp. infest most of the food legumes, but cause economic damage in blackgram, greengram, and Phaseolus beans. Pod sucking bugs (Clavigralla tomentosicollis Stal., C. gibbosa Spin., Nezara viridula L. and Bagrada hilaris Burm.) are occasional pests, but extensive damage has been recorded in cowpea by $C$. tomentosicollis in Africa, and C. gibbosa in pigeonpea in India. The redlegged earth mite, Halotydeus destructor Tucker is a seedling pest of field peas in Australia (Thackray et al., 1997; Ridsdill-Smith, 1997; Liu and Ridsdill-Smith, 2001). The pea and bean weevil, Sitona lineatus L. is a pest of field pea in the U.S. Pacific Northwest, while $S$. crinitus Herbst. is a pest of pea and other legumes in Asia. The thrips, Megaleurothrips dorsalis Karny and Caliothrips indicus Bag. cause extensive flower damage in food legumes. The bruchids, Callasobruchus chinensis L. and C. maculatus Fab. cause extensive losses in storage in all the food legumes worldwide. The pea weevil, Bruchus pisorum L. is a major pest of field pea in most production areas (Clement et al., 1999).

The geographical distribution of some of the pest will extend northwards, while the outbreaks of some other pests will become more frequent as a result of global warming. The relative importance of many of these insects will also change under global warming and climate change. The pod borers, $H$. armigera and $M$. vitrata, which are confined to tropics, may extend their range of geographical distribution to northern Europe, while there may be more number of generations due to shortening of development time due to rise in temperature. Reduced activity of natural enemies under warm and dry climates might increase the severity of damage by some pest species.

\subsection{Extent of Losses}

Insect pests in India cause an average of 30\% loss in pulses valued at \$815 million, which at times can be $100 \%$ (Dhaliwal and Arora, 1994). In Africa, insect pests can be responsible for extensive damage (up to 100\%) in cowpea, the major food legume on this continent (Singh and Jackai, 1985), while in the U.S., the avoidable losses have been estimated at 40-45\% (Javaid et al., 2005). In Pakistan, nearly 10\% of the chickpea grain is lost due to bruchids in storage (Aslam, 2004), and at times, 
there may be complete loss of grain in storage. Helicoverpa armigera - the single largest yield reducing factor in food legumes, causes an estimated loss of US\$ 317 million in pigeonpea, and \$328 million in chickpea (ICRISAT, 1992). Globally, it causes an estimated loss of over $\$ 2$ billion annually, despite over \$1 billion worth of insecticides used to control this pest (Sharma, 2005). In general, the estimates of yield losses vary from 5 to $10 \%$ in the temperate regions and 50 to $100 \%$ in the tropics (van Emden et al., 1988). The avoidable losses in food legumes at current production levels of 60.45 million tonnes would be nearly 18.14 million tons (at an average loss of 30\%), valued at nearly US\$ 10 billion (Sharma et al., 2008).

\subsection{Pest Management in Grain Legumes Under Climate Change}

\subsubsection{Monitoring and Sampling of Pest Populations}

Monitoring of pest populations is the key to determine if a threshold has been exceeded and control measures are required (Sharma et al., 2002). Monitoring of pest populations through light or pheromone traps has been practiced for H. armigera in Asia (Trivedi et al., 2005) and H. punctigera in Australia (Loss et al., 1998). Sampling based on direct counts or insect damage has also been used for H. armigera in chickpea and pigeonpea (Wightman et al., 1995), H. punctigera in chickpea (Loss et al., 1998), M. vitrata in cowpea (Jackai, 1990; Oghiakhe et al., 1992), L. cicerina in chickpea (Weigand and Pimbert, 1993), B. pisorum in field pea (Smith and Hepworth, 1992), pea and bean weevil, S. lineatus in faba bean (Ward and Morse, 1995) and field pea (O'Keeffe et al., 1991)., S. crinitis Herbst. in lentil (Kaya and Hincal, 1987), A. fabae in faba bean (Ward and Morse, 1995), and A. pisum in field pea (Soroka and Mackay, 1990). Sweep net method has been used for Lygus hespersus Knight (Schotzko and O'Keeffe, 1989), H. punctigera (Loss et al., 1998), B. pisorum (Smith and Hepworth, 1992), and A. pisum (Maiteki and Lamb, 1985). Soil sampling has been used to assess egg density of Sitona spp. (Nielsen, 1990). Plant shaking has been employed to dislodge the larvae of H. punctigera on different crops in Australia (McIntyre and Titmarsh, 1989; Loss et al., 1998). Under global warming and climate change, there has to be a greater emphasis on regular scouting of pest populations, and use this information for forecasting pest populations, severity of damage, and pest outbreaks.

\subsubsection{Economic Thresholds}

Economic or action thresholds have often been used to time insecticide sprays or other interventions aimed at pest suppression. Economic thresholds have been determined for $H$. armigera on pigeonpea (one egg or larva per plant or $2 \%$ pod damage) (Goyal et al., 1990; Meenakshisundaram and Gujar, 1998) and chickpea (one larva per meter row) (Wightman et al., 1995; Khurana, 1997). Economic thresholds have 
been established for $H$. punctigera on chickpea in Australia (Loss et al., 1998), and B. pisorum on field pea (Horne and Bailey, 1991). Additionally, economic thresholds based on sweep net sampling have been established for A. pisum (Maiteki and Lamb, 1985, Loss et al., 1998). Small producers in many developing countries have limited resources, and are unwilling to spend money on insect control until damage is visible or large larvae are seen on the crop. At low population levels, this may be a good policy. However, when infestations are heavy, by the time spraying commences, the damage has already been done. Therefore, it is important to monitor adults, eggs and early larval growth stages, as well as plant damage, to undertake appropriate control measures in time.

\subsubsection{Cultural Practices}

Early and timely planting of crops can help avoid periods of peak abundance of $H$. armigera in chickpea and pigeonpea in India (Weigand et al., 1994; Dahiya et al., 1999). However, early planting of chickpea is ineffective in southern India because of moderate temperatures during the crop-growing season, which sustain high populations of $H$. armigera. Early and timely planting might become more uncertain under global warming and climate change, e.g., during the 2009 rainy season, delay in onset of monsoons by 45 days resulted in delayed plantings of pigeonpea that are more prone to damage by $H$. armigera, while heavy downpour during August lead to $H$. armigera outbreak on soybean (due to dense crop canopy and absence of other suitable hosts), on which it was a minor pest till recently. High planting densities aggravate $H$. armigera infestation in chickpea (Reed et al., 1987). Use of short-duration cultivars has often been used to avoid pest damage, but short-duration pigeonpea suffers greater damage by the spotted pod borer, M. vitrata in southern India. Increased infestations of Sitona spp. have been observed in late sown crops in Syria. Winter-sown chickpea suffers less damage by the leaf miner than the spring-sown one (Weigand et al., 1994). Early harvesting of peas reduces the losses due to B. pisorum in Australia (Baker, 1990a, b).

Deep ploughing of fields before planting and after crop harvest can expose insect pupae in the soil to biotic and abiotic mortality factors. For example, deep ploughing destroys the over-wintering population of $H$. armigera and other noctuids (Rummel and Neece, 1989; Fitt and Cotter, 2005). During intercultural operations, birds such as common Myna (Acridotheres tristis L.), egrets (Egretta spp.), and drongos (Dicrurus adsimilis L.) follow the ploughshare to eat insects that are exposed. Heavy fertilizer application results in luxuriant plant growth resulting in greater damage due to insect pests. Early termination of flowering and fruiting also reduces the population carryover from one season to another, and also reduces the number of generations of $H$. armigera (Fitt, 1989).

Careful selection of a cropping system can also minimize the losses due to insect pests. Intercropping chickpea with mustard, linseed, or safflower (Das, 1998), and pigeonpea with cowpea (Hegde and Lingappa, 1996) and sorghum (Mohammed 
and Rao, 1999) result in reduced damage by H. armigera. Intercropping can also be used as a means of encouraging the activity of natural enemies (Bhatnagar et al., 1983). Planting non-host crops before the planting of susceptible legume crops such as pea and faba bean reduces the damage by the red legged earth mite (RidsdillSmith, 1997). Trap crops and diversionary hosts have been widely used to reduce the damage by $H$. armigera, but there is little data to demonstrate their effectiveness under field conditions (Pearson, 1958; Fitt, 1989). Marigold, sesame, sunflower, and carrots can be used as trap crops for H. armigera. In Australia, chickpea and pigeonpea are used as trap crops in cotton growing regions to reduce damage by $H$. armigera. Use of plant kairomones to lure B. pisorum (Clement et al., 2000) and H. armigera (Rembold and Tober, 1985; Rembold et al., 1990) into traps or toxin baits has also been suggested. Hand picking of the larvae, nipping the plant terminals with eggs, and shaking the plants to dislodge the larvae (particularly in pigeonpea) has been suggested to reduce $H$. armigera damage (Ranga Rao et al., 2005). Crops that can serve as perches for insectivorous birds (e.g., sunflower in chickpea) or provision of bird perches can also be used to increase the predation by insectivorous birds such as myna and drongo. Egg masses and larvae of S. litura and Amsacta spp. can also be picked up by hand and destroyed. Irrigation or flooding of fields at the time of pupation reduces pupal survival and leads to decreased population densities in the following generation or season (Murray and Zalucki, 1990).

\subsubsection{Host Plant Resistance}

Grain legume germplasm with resistance to insect pests has been identified, but the sources of resistance have not been used extensively in breeding programs (Clement et al., 1994, Sharma and Ortiz, 2002). Insect resistance-breeding programs are underway for a few crop pests only. Entomologists and plant breeders have experienced difficulties in screening and selecting for resistance to target pests, in part, because of the lack of uniform insect infestations across locations and seasons. In addition, it is difficult to rear and multiply some of the insect species on synthetic diets for artificial infestation. Cultivars with resistance to insect pests have been identified in pigeonpea, chickpea, cowpea, black gram, green gram, and field pea (Table 7.2). However, the levels of resistance are low to moderate, but are quite effective when deployed in combination with synthetic pesticides or natural plant products such as neem seed kernel extract (Sharma and Pampapathy, 2004). Cultivars with multiple-resistance to insects and diseases will be in greater demand in future because of the concerns associated with chemical control and environmental pollution and the changes in relative importance and severity of damage due to climate change. There is a need to break the linkage between insect resistance and susceptibility to diseases, e.g., in chickpea and pigeonpea, H. armigera-resistant cultivars are susceptible to wilt (Sharma et al., 2005). In Australia, narrow-leafed lupins, Lupinus angustifolius, with resistance to aphids (Kalya and Tanjil) are being used in the field, which have greatly reduced the need to apply insecticides (Edwards et al., 2003). 
Table 7.2 Identification and utilization of host plant resistance to insect pests in grain legumes

\begin{tabular}{|c|c|c|}
\hline Crop & Genotypes & Reference \\
\hline Pigeonpea & $\begin{array}{l}\text { Pod borer, Helicoverpa armigera } \\
\text { ICPL 332*, PPE 45-2, ICPL 84060, BDN 2, ICPL } \\
\text { 4, Bori, T 21, ICP 7035, and ICPL 88039. } \\
\text { Pod fly, Melanagromyza obtusa } \\
\text { ICP 10531-E1, ICP 7941E1, ICP 7946-E1, and } \\
\text { ICP 7176-5. }\end{array}$ & $\begin{array}{l}\text { Lateef and Pimbert } \\
\text { (1990), Kalariya } \\
\text { et al. (1998), } \\
\text { Parsai (1996). } \\
\text { Lateef and Pimbert } \\
\text { (1990). }\end{array}$ \\
\hline Chickpea & $\begin{array}{l}\text { Pod borer, Helicoverpa armigera } \\
\text { ICC 506, ICCV 7*, ICCV } 10^{*} \text {, Dulia*, C 235*, JG } \\
79^{*} \text {, BJ 256*, Vijay, and Vishal. } \\
\text { Leaf miner, Liriomyza cicerina } \\
\text { ILC } 380 \text {, ILC 5901, and ILC } 7738 .\end{array}$ & $\begin{array}{l}\text { Lateef and Sachan } \\
\text { (1990), Bhagwat } \\
\text { et al. (1995), Das } \\
\text { and Kataria } \\
\text { (1999), Deshmukh } \\
\text { et al. (1996a, b). } \\
\text { Singh and Weigand } \\
\text { (1996). }\end{array}$ \\
\hline Blackgram & $\begin{array}{l}\text { Pod borer, Helicoverpa armigera } \\
\text { Kalai*, } 338-3 \text {, Krishna*, and Co } 3^{*}, 4^{*} \text { and } 5^{*} \text {. } \\
\text { Jassid, Empoasca kerri } \\
\text { Sinkheda } 1^{*} \text {, Krishna*, H } 70-3 \text {, and UPB } 1^{*} \text {. } \\
\text { Stem fly, Ophiomyia phaseoli } \\
\text { Killikullam*, 338/3, P } 58, \text { Co } 4^{*} \text {, and Co } 5^{*} \text {. }\end{array}$ & Lal (1987). \\
\hline Greengram & $\begin{array}{l}\text { Pod borer, Maruca vitrata } \\
\text { J1, LM 11, P 526, and P } 336 \text {. } \\
\text { ML 337, ML 5, MH 85-61, and ML } 325 . \\
\text { Stem fly, Ophiomyia centrosematis } \\
\text { Co } 3 \text {. }\end{array}$ & $\begin{array}{l}\text { Lakshminarayana } \\
\text { and Misra (1992). }\end{array}$ \\
\hline Field pea & $\begin{array}{l}\text { Pod borer, Etiella zinkenella } \\
\text { EC } 33860 \text {, Bonville*, T } 6113^{*}, \text { PS 410, 2S 21, } \\
\text { and } 172 \text { M. } \\
\text { Leaf miner, Chromatomyia horticola } \\
\text { P 402, PS 41-6, T 6113, PS 40, KMPR 9, P 402, } \\
\text { and P } 200 .\end{array}$ & Lal (1987). \\
\hline Cowpea & $\begin{array}{l}\text { Pod borer, Maruca vitrata } \\
\text { TVu 946, VITA 4, VITA 5, Ife Brown, and } \\
\text { Banswara*. } \\
\text { Jassid, Empoasca kerri } \\
\text { TVu 123, TVu 662, JG 10-72, C 152, and 3-779 } \\
\text { (1159). } \\
\text { Aphid, Aphis craccivora } \\
\text { P 1473, P 1476, and MS 9369. }\end{array}$ & $\begin{array}{l}\text { Singh (1978), Lal } \\
\text { (1987). }\end{array}$ \\
\hline
\end{tabular}

\footnotetext{
* Released for cultivation.
}

Screening of entire germplasm collections of chickpea and pigeonpea (over 15,000 accessions for each crop) has led to identification of a few accessions with moderate levels of resistance to $H$. armigera (Lateef, 1985; Lateef and Pimbert, 1990). However, lack of precision in evaluating thousands of accessions for resistance to the target pests probably resulted in missing many potentially good sources of resistance. In lentil, genotypic differences for susceptibility to aphid (A. craccivora), pod borer (E. zinkenella), and seed weevil have been observed, 
but no attempts have been made to breed for resistance to insects (Erskine et al., 1994). Sources of resistance to chickpea leaf miner have been identified, and used successfully in the breeding program (Singh and Weigand, 1996). Climate change may alter the interactions between the insect pests and their host plants. Hence, development of cultivars with stable resistance to pests would provide an effective approach in pest management. Problems with new agricultural pests will occur if climatic changes favor the introduction of cultivars that are highly susceptible to the prevalent pest spectrum. Therefore, it is important to identify and develop cultivars that are stable in expression of resistance to the target pests under variable climate.

\subsubsection{Biological Control}

The importance of both biotic and abiotic factors on seasonal abundance of insect pests is poorly understood. Early stage mortality is invariably the most severe, although its causes and extent vary greatly, and comparable data sets are too few to identify the factors responsible for population regulation across regions. There is voluminous information on parasitism, and to a lesser extent on predation of insect pests on different food legumes. The egg parasitoids, Trichogramma spp. and Telenomus spp. destroy large numbers of eggs of $H$. armigera and $H$. punctigera, but their activity levels are too low in chickpea and pigeonpea because of trichome exudates. The ichneumonid, Campoletis chlorideae Uchida is probably the most important larval parasitoid of $H$. armigera on chickpea and pigeonpea in India (Pawar et al., 1986). Tachinids parasitize late-instar H. armigera larvae, but result in little reduction in larval density. In India, Carcelia illota (Curran), and to a lesser extent, Goniophthalmus halli Mesnil, and Palexorista laxa (Curran) parasitize up to $22 \%$ of $H$. armigera larvae on pigeonpea (Bhatnagar et al., 1983), and up to $54 \%$ larvae in chickpea. There are a few reliable estimates of pre-pupal and pupal mortality of $H$. armigera, which may be as high as $80 \%$ (King, 1994). Six species of parasitoids have been recorded from field-collected Helicoverpa pupae (Fitt, 1989). Population of L. cicerina parasitoids builds up late in the season in West Asia (Weigand et al., 1994). Potential biocontrol agents for B. pisorum have been documented (Annis and O'Keeffe, 1987; Baker, 1990a, b). The most common predators of insect pests of food legumes are Chrysopa spp., Chrysoperla spp., Nabis spp., Geocoris spp., Orius spp., Polistes spp., and species belonging to Pentatomidae, Reduviidae, Coccinellidae, Carabidae, Formicidae and Araneida (Zalucki et al., 1986; van den Berg et al., 1988; Romeis and Shanower, 1996; Sharma, 2001). Some predators have been used in augmentative release studies, notably Chrysoperla carnea (Stephens) (Ridgeway et al., 1977). Although effective in large numbers, the high cost of large-scale production precludes their economic use in biological control in food legumes (King et al., 1986). Relationships between pests and their natural enemies will change as a result of global warming, resulting in both increases and decreases in the status of individual species. Quantifying the effect of climate change on the activity and effectiveness of natural enemies will be a major concern in future pest management programs. 
There is considerable information on entomophagous pathogens against $H$. armigera and $H$. punctigera, although to date, these tactics have not provided a viable alternative to insecticides. Spraying Bacillus thuringiensis (Bt) (Berliner) formulations in the evening results in better control than spraying at other times of the day (Mahapatro and Gupta, 1999). The entomopathogenic fungus Nomuraea rileyi (Farlow) Samson (@ 106 spores per ml) resulted in 90-100\% larval mortality, while Beauveria bassiana Balsamo (@2.68 × 10 ${ }^{7}$ spores per ml) resulted in 6\% damage on chickpea compared to $16.3 \%$ damage in untreated control plots (Saxena and Ahmad, 1997). A significant and negative correlation has been observed between insect mortality due to NPV and foliar $\mathrm{pH}$, phenols, tannins, and protein binding capacity (Ramarethinam et al., 1998). In Australia, a commercially available NPV has been tested on cotton, with an additive that increases the level of control. Neem and custard apple extracts, and neem and karanj (Pongamia) oil based formulations have also been recommended for the management of $H$. armigera (Ranga Rao et al., 2005). Much remains to be done to develop stable and effective formulations of biopesticides for the control of $H$. armigera and other insect pests on food legumes. Vegetable oils, neem oil and karanj oil provide effective protection against bruchid damage in pulses (Reddy et al., 1996). Karanj oil, and leaf and seed extracts act as oviposition deterrents (Kumar and Singh, 2002). There is a need for a greater understanding of the effect of climate change on the efficacy of biopesticides for pest management.

\subsubsection{Chemical Control}

Management of insect pests in food legumes relies heavily on insecticides, often to the exclusion of other methods. Control measures directed at adults, eggs, and neonate larvae are most effective in minimizing $H$. armigera damage. Spray decisions based on egg counts could destroy both invading adults and eggs, and leave a residue to kill future eggs and neonate larvae. Young larvae are difficult to find as they burrow into the flowers where they become less accessible to contact insecticides. Spray initiation at $50 \%$ flowering has been found to be most effective (Singh and Gupta, 1997). As a result of heavy selection pressure, $H$. armigera has developed resistance to the major classes of insecticides. Helicoverpa armigera populations have shown resistance to endosulfan, thiodicarb, and methomyl in Australia (Daly et al., 1988; Gunning et al., 1996); cypermethrin, endosulfan, quinalphos, monocrotophos, carbaryl, chlorpyrifos, phosalone, fenvalerate, and deltamethrin in India (Armes et al., 1996; Kranthi et al., 2002); cypermethrin, cyfluthrin, deltamethrin, bifenthrin, lambda-cyhalothrin, monocrotophos, ethion, chlorpyriphos, and profenfos in Pakistan (Ahmad et al., 1997a, b); and fenvalerate in Thailand (Burikam et al., 1998). Insecticide resistance management strategies have been developed in several countries to prevent the development of resistance or to contain it. All strategies rely on a strict temporal restriction in the use of pyrethroids and their alteration with other insecticide groups to minimize selection for resistance (Sawicki and Denholm, 1987). Considerable information 
has also been generated on chemical control of B. pisorum in pea (Michael et al., 1990), S. lineatus and A. fabae in faba bean (Ward and Morse, 1995), and aphid vectors in lupins (Bwye et al., 1997). There is a need for a greater understanding of the effect of climate change on the efficacy of synthetic insecticides, their persistence in the environment, and development of resistance in pest populations.

\subsection{Biotechnological Approaches for Pest Management in Grain Legumes}

\subsubsection{Transgenics}

While several transgenic crops with insecticidal genes have been introduced in the temperate regions, very little has been done to use this technology for improving crop productivity in the harsh environments of the tropics, where the need for increasing food production is most urgent (Sharma et al., 2004; Sharma, 2009). Progress in developing transgenic plants of food legumes has been reviewed by Popelka et al. (2004). Chickpea cultivars ICCV 1 and ICCV 6, transformed with crylAc gene, have been found to inhibit the development of and feeding by $H$. armigera (Kar et al., 1997). Transgenic pigeonpea plants with crylAb and soybean trypsin inhibitor ( $S B T I)$ genes have been developed at ICRISAT, and are being tested against $H$. armigera (Gopalaswamy et al., 2008). Transgenic chickpea expressing cowpea trypsin inhibitor (Thu et al., 2003), and $\alpha$-amylase inhibitor (Shade et al., 1994; Schroeder et al., 1995; Sarmah et al., 2004) with resistance to bruchids has also been developed. Research in Australia has led to the development of transgenic pea for resistance to pea weevil through the expression of $\alpha$-amylase inhibitor (Morton et al., 2000), but this technology is not available to pea breeders in Australia, the USA, and other countries because of the concerns associated with the use of transgenic crops as food.

\subsubsection{Molecular Markers}

The use of DNA markers for indirect selection offers the greatest potential gains for quantitative traits with low heritability, as these are the most difficult characters to work with through conventional phenotypic selection. The quality of a markerassisted selection program can only be as good as the quality of the phenotypic data on which the development of that marker was based. Therefore, it is essential to use large mapping populations characterized across seasons and locations, and using well-defined phenotyping protocols. Progress in marker-aided selection for resistance to insect pests in grain legumes though limited, and been discussed by Sharma et al. (2008). Mapping the complex traits such as resistance to pod borer, $H$. armigera in chickpea is only just beginning (Lawlor et al., 1998). A mapping population derived from a cross between a wilt-resistant Kabuli variety (ICCV 2) 
and a wilt-susceptible Desi variety (JG 62) has been used to develop the first intraspecific genetic linkage map of chickpea (Cho et al., 2002). This population has also been evaluated for resistance to $H$. armigera, and the data analysis is in progress. An interspecific population derived from ICC 4958 (Cicer arietinum) $\times$ PI 489777 (Cicer reticulatum) has been evaluated for resistance to beet armyworm, Spodoptera exigua (Hub.) (Clement et al., 2008) and pod borer, H. armigera (Sharma, H.C., Unpublished), and this population is being genotyped to identify markers for resistance to these insects. Another mapping population (Vijay $\times$ ICC $506 \mathrm{~EB}$ ) has also been developed and evaluated for resistance to H. armigera. In pigeonpea, a mapping population involving $C$. cajan $\times C$. scarabaeoides is under development at ICRISAT (Upadhyaya, H.D., personal communication).

A cross between an aphid (A. craccivora) resistant cultivated cowpea (IT 84S2246-4) and an aphid susceptible wild cowpea (NI 963) has been evaluated for aphid resistance and RFLP (restricted fragment length polymorphism) marker segregation (Myers et al., 1996). The RFLP marker $b g 4 D 9 b$ was linked to the aphid resistance gene $(\mathrm{Racl})$, and several flanking markers in the same linkage group (linkage group 1) have also been identified. Tar'an et al. (2002) developed the genetic linkage map of common bean. Murray et al. (2004) detected genetic loci for resistance to potato leafhopper, Empoasca fabae (Harris). In greengram, TC1966 bruchid resistance gene has been mapped using RFLP markers (Young et al., 1992). Resistance was mapped to a single locus on linkage group VIII (approximately $3.6 \mathrm{cM}$ from the nearest RFLP marker). Based on RFLP analysis, a progeny was also identified in the $\mathrm{F}_{2}$ population that retained the bruchid resistance gene within a tightly linked double crossover. This progeny might be useful in developing mungbean lines resistant to bruchids, and free of linkage drag. Yang et al. (1998) used RFLP marker-assisted selection in backcross breeding for introgression of the bruchid resistance gene in greengram, while Kaga and Ishimoto (1998) studied genetic localization of a bruchid resistance gene and its relationship to insecticidal cyclopeptide alkaloids, the vignatic acids in greengram. The random amplified polymorphic DNA (RAPD) markers have also been used to identify markers linked to the bruchid resistance in mungbean (Villareal et al., 1998). The gene was $25 \mathrm{cM}$ from $p M 151 a$. When $p M 151 a$ and $p M 151 b$ were considered as alleles of the same locus, the bruchid resistance gene was located $11.9 \mathrm{cM}$ from the nearest RAPD marker Q04 sub 900, and $5.6 \mathrm{cM}$ from pM151. Progress has also been made in locating molecular markers for resistance to pea weevil in crosses between field pea ( $P$. sativum) and the wild species ( $P$. fulvum) (Byrne et al., 2002).

\subsection{Storage Pests and Their Management}

Bruchids, Callosobruchus chinensis and C. maculatus are the most important pests of grain legumes in storage, including chickpea and lentil. Bruchid infestation in grain legumes commences in the field even before the crop harvest, and then they multiply quite fast in storage, resulting in heavy losses. The Callosobruchus 
species are commonly known as spotted pulse beetle, Oriental pulse beetle, bruchid, bean weevil, bruchid seed beetle, gram bean weevil, southern cowpea weevil, cowpea weevil, etc. Callosobruchus chinensis and $C$. maculatus are cosmopolitan in distribution, encompassing Australia and Oceania, Europe, Asia, Africa, and the Americas (Rees, 2004). The members of the family Bruchidae have long been reported to destroy the seeds of leguminous plants. They also feed on seeds and flowers of non-leguminous plants belonging to the families Compositae, Malvaceae, Convolvulaceae, Anacardiaceae, Rosaceae, Umbelliferae, Papavaraceae, and Palmae (Arora, 1977). Among the several species of bruchids attacking edible legumes, $C$. maculatus and $C$. chinensis are most destructive, and attack almost all edible legumes, including chickpea and lentil.

Females of $C$. maculatus and $C$. chinensis lay eggs singly on seeds, which are visible to the naked eye. Bruchids tend to lay eggs singly on a given host and if all the seeds are occupied, then the female starts laying eggs on already egg-laden seeds (Messina and Renwick, 1985). The neonate larva bores into the seed beneath the oviposition site, and completes its development within a single seed. Damaged seeds are riddled with adult emergence holes, which are unfit for human or animal consumption (Schoonhoven and Cardona, 1986). The life cycle of bruchids passes through five larval instars, three pre-pupal stages, pupal, and adult stages. The egg incubation period of $C$. maculatus in green gram lasts for 3-5 days, and the combined larval and pupal period lasts for nearly 19 days. Total development is completed in about 24 days. The adults of $C$. chinensis and $C$. maculatus are easily distinguishable with the naked eyes.

\subsubsection{Pre-harvest Control}

Spraying monocrotophos $(0.04 \%)$, fenvalerate $(0.02 \%)$, and dimethoate $(0.03 \%)$ at 45 and 50 days after flowering of pulses reduces $C$. chinensis damage in stored pigeonpea (Subramanya et al., 1999). Similarly, cowpea protected by spraying malathion $(0.05 \%)$ at maturity reduces the bruchid damage (Ravindra, 1999). At pod maturity, the dehisced pods with exposed seeds are more vulnerable to oviposition by bruchids, and this problem can be avoided by harvesting the crop at physiological maturity.

\subsubsection{Hermetic Storage}

Storing grain legumes in polythene bags with a cotton lining has been found effective against $C$. maculatus (Caswell, 1973). Even though the adult females could penetrate the polythene bags, the cotton lining posed hindrance for oviposition, leaving the grains safe. Bagged grains encased in polythene sacks are also less damaged by the bruchids (Wilkin and Green, 1970). 


\subsubsection{Solar Treatment}

High temperatures due to solar radiation have been found to kill developing bruchid larvae in the seeds (Zehrer, 1980). Exposing grain legumes to $70-80^{\circ} \mathrm{C}$ temperature for short duration has been found to be effective in reducing the bruchid infestation. Solar heaters operated at $65^{\circ} \mathrm{C}$ for 5 min provide $100 \%$ control of C. maculatus (Murdock and Shade, 1991). Solar heat treatment is being used in India for disinfesting the grains.

\subsubsection{Use of Inert Dusts}

Dusts remove the epicuticular lipid layer of the insects and have been used effectively against bruchids. Some of the dusts in use include bentonite clay, hydrated lime, attapulgite dust, limes, clays, synthetic silica, and sand. Treatment of pulses with fly ash also hinders emergence of $C$. maculatus adults up to 12 months.

\subsubsection{Use of Traps}

Pitfall traps can be used for capturing insects that are active on the grain surface, and in other layers of grain. It also serves as a monitoring cum mass trapping tool. Two models are available viz., standard model and the TNAU model (Mohan and Fields, 2002). A standard model has 2 parts, perforated lid (2-3 mm) and a cone shaped bottom portion. A special coating with sticky material on the inner side of cone to hold the trapped insects is essential. The model devised by Mohan and Fields (2002) has a perforated lid and a cone shaped bottom, which tapers into a funnel shaped trapping tube. It is made of plastic, and is simple and economical. Another two-in-one trap is a combination of probe and pitfall traps, and is designed to increase the trapping efficiency. This trap is also suitable for pulse beetles as they are seen only on grain surface. It does not require coating on the inner surface with sticky materials. Beetles are captured alive in this trap. The release of pheromone by the trapped insects attracts more insects.

\subsubsection{Chemical Control}

Chemical methods such as fumigation with phosphine, methyl bromide, or dusting with primiphos methyl and permethrin are effective against bruchids, but have certain disadvantages such as increased costs, handling hazards, pesticide residue, and possibility of development of resistance. With the proposed ban of fumigants by 2015 , there is an urgent need to develop safer alternatives to conventional insecticides and fumigants to protect stored grain from insect pests. 


\subsubsection{Host Plant Resistance}

Several cultivars of different grain legumes have been reported to be resistant to C. maculatus (Lambrides and Imrie, 2000; Riaz et al., 2000; Khattak et al., 2001; Jha, 2002). Apart from the cultigens, wild relatives of several grain legumes have shown high levels of resistance to bruchids. Several varieties have been developed by crossing wild species with of the cultigens, and the results have been highly promising.

\subsubsection{Natural Plant Products}

Neem, Azadirachta indica (A. Juss) possesses antifeedant, oviposition repellant, ovicidal, and adulticidal properties against bruchids (Said, 2004; Singh and Mehta, 1998). Seed treatment with neem leaf powder at $0.5-2.0 \mathrm{mg} 100 \mathrm{~g}^{-1}$ of grain, neem seed kernel powder, neem bark powder, and neem seed oil at 3\% have been reported to be effective against bruchids. Neem oil and Pongamia oil reduce seed damage by C. maculatus (Durairaj and Muthiah, 2003). Singh et al. (2003) suggested the use of coconut, mustard, and groundnut oil (@12 ml kg-1) to suppress adult emergence for two consecutive generations. Volatile oils of Cymbopogan nardus $(L)$ and $C$. schoenanthus., Clausena anisata (Wild.) Hook f. ex. Benth, C. citratus (DC) Stapf., and Ocimum basilicum L. have oviposition repellent and adulticidal effects (Boeke et al., 2004; Aslam et al., 2002). Lantana camara L. and Parthenium hysterophorus $L$. have also been reported to be repellent to pulse beetle in chickpea.

\subsubsection{Strategies for Controlling Bruchid Damage in the Field and Storage}

Prevention of infestation in the field through timely harvest of the crop or insecticide use can be quite useful for reducing bruchid infestation. Optimum drying of the grain, use of solar radiation to kill the bruchids infesting the grain, and storing the grain in polyethylene bags can be used to reduce bruchid infestation. Dusts, neem leaf or kernel powder, treatment of seed with neem, Pongamia, or other vegetable oils can be used for minimizing the losses due to bruchids. Under severe infestation, the grain should be fumigated to get rid of bruchids infesting the grain. An ideal IPM schedule should be as follows: spraying monocrotophos or dimethoate at pod formation stage and just before pod maturity to reduce infestation by bruchids in the field, reducing the moisture content of the grains to less that $12 \%$ before storage, using cotton lined polythene bags for storage, treatment of grains with inert dusts such as clay, silica, fine sand, or fly ash, use of pitfall traps as a low cost device for use in households and medium scale storage, and treatment of grain with botanicals such as neem oil, neem leaf powder, etc. Though the above methods are economical, developing durable varieties with resistance to bruchids through interspecific 
hybridization and genetic transformation would be helpful in the long run. Use of biocontrol agents, semiochemicals, and controlled atmosphere storage (CAS) has been found to be very effective, and can be used for minimizing the losses due to bruchids.

\subsection{Conclusions}

There is considerable information on the insect pests that damage food legumes in different countries, although the factors that influence the population build up and population dynamics of many insect species is not sufficiently clearly understood. There is a need to gain a thorough understanding of the factors that lead to heavy losses in food legumes. Cultivars with resistance to insect pests will play a pivotal role in pest management in food legumes, but only if breeding programs utilize identified sources of resistance. Resistance genes from closely related wild relatives of grain legumes should also be utilized wherever possible. Genetically engineered plants with different insecticidal genes can also play a role in IPM. Molecular marker-assisted selection has the potential to pyramid resistance genes and other desirable traits to magnify the value of host plant resistance in food legume IPM. Moreover, cultural practices that reduce the intensity of insect pests are another important element of pest control. Cropping systems that encourage the activity and abundance of natural enemies should be popularized among the farmers. Insecticides provide quick and effective pest control in food legumes. However, where insecticide resistance has developed as in case of Helicoverpa, a more integrative strategy may be needed. Neem seed kernel extract, Bt, and HaNPV have been recommended in many cases, but limitations on timely availability, quality control, and economic feasibility limit their use in pest management on a regular basis. However, biopesticides applied in combination with synthetic insecticides or in rotation can be quite effective for pest management on different crops. Release of natural enemies for biological control has been successful in some situations. The integrated strategy has to be developed for each region to suit the farming practices of the growers in that region. As a result of climate change, earlier emergence of pests and faster generation turnover will result in problems with the timing of pest control interventions. There is a need for a greater understanding of the effect of climate change on the efficacy of natural enemies, host plant resistance to insects, biopesticides and synthetic insecticides, and their persistence in the environment to develop effective strategies for pest management in grain legumes in future.

\section{References}

M. Ahmad, M.I. Arif, and M.R. Attique (1997a). Patterns of resistance to organophosphate insecticides in field populations of Helicoverpa armigera in Pakistan. Pestic Sci 55, 626-632.

M. Ahmad, M.I. Arif, and M.R. Attique (1997b). Pyrethroid resistance of Helicoverpa armigera (Lepidoptera: Noctuidae) in Pakistan. Bull Entomol Res 87, 343-347. 
B. Annis and L.E. O'Keeffe (1987). Influence of pea genotype on parasitization of the pea weevil, Bruchus pisorum (Coleoptera: Bruchidae) by Eupteromalus leguminis (Hymenoptera: Pteromalidae). Environ Entomol 16, 653-655.

N.J. Armes, D.R. Jadhav, and K.R. De Souza (1996). A survey of insecticide resistance in Helicoverpa armigera in the Indian sub-continent. Bull Entomol Res 86, 499-514.

G.L. Arora (1977). Taxonomy of the Bruchidae of North West India. Orient Insects 7, 132.

M. Aslam (2004). Pest status of stored chickpea beetle, Collasobruchus chinenesis Linnaeus on chickpea. J Entomol 1, 28-33.

M. Aslam, K.A. Khan, and M.Z.H. Bajwa (2002). Potency of some spices against Callosobruchus chinensis Linn. J Biol Sci 2(7), 449-452.

G.H. Baker (1990a). Natural enemies of pea weevil, Bruchus pisorum (Bruchidae), worthy of consideration as biological control agents. In: Smith, A.M., (ed.), Workshop Proceedings: National Pea Weevil Workshop, pp. 80-83. Victoria Department of Agriculture and Rural Affairs, Melbourne.

G.H. Baker (1990b). Future research on biological control of pea weevil, Bruchus pisorum (Bruchidae). In: Smith, A.M. (ed.), Workshop Proceedings: National Pea Weevil Workshop, pp. 84-86. Victoria Department of Agriculture and Rural Affairs, Melbourne.

V.R. Bhagwat, S.K. Aherker, V.S. Satpute, and H.S. Thakre (1995). Screening of chickpea (Cicer arietinum L.) genotypes for resistance to Helicoverpa armigera (Hub.) and its relationship with malic acid in leaf exudates. J Entomol Res 19, 249-253.

V.S. Bhatnagar, S. Sithanantham, C.S. Pawar, D.S. Jadhav, V.K. Rao, and W. Reed (1983). Conservation and augmentation of natural enemies with reference to IPM in chickpea and pigeonpea. Proceedings of the International Workshop on Integrated Pest Control in Grain Legumes, 4-9 April 1983, pp, 157-180. Empresa M Braseleira Pesquisa Agropocuria (EMRAPA), Goiania, Brazil.

S.J. Boeke, C. Barnaud, J.J.A.V. Loon, D.K. Kossou, A.V. Huis, and M. Dicke (2004). Efficacy of plant extracts against the cowpea beetle, Callosobruchus maculatus. Int J Pest Manage 50(4), 251-258.

I. Burikam, P. Marasri, and P. Pompranee (1998). Resistance to synthetic pyrethroids of Helicoverpa armigera (Hubner) (Lepidoptera: Noctuidae) in Thailand. Thai J Agric Sci 31, 174-183.

A.M. Bwye, W. Proudlove, F.A. Berlandier, and R.A.C. Jones (1997). Effects of applying insecticides to control aphid vectors and cucumber mosaic virus in narrow-leafed lupins (Lupinus angustifolius). Aust J Exp Agric 37, 93-102.

O. Byrne, N. Galwey, and D. Hardie (2002). Searching for molecular markers for resistance to pea weevil. In: McComb, J.A. (ed.), Plant Breeding for the 11th Milennium Proceedings of the 12th Australasian Plant Breeding Conference, pp. 362-366. Australian Plant Breeding Association, Inc., Perth, Western Australia.

G.H. Caswell (1973). The impact of infestation on commodities. Trop Stored Prod Inf 25, 19.

S. Cho, J. Kumar, J. Shultz, K. Anupama, F. Tefera, and F.J. Muehlbauer (2002). Mapping genes for double podding and other morphological traits in chickpea. Euphytica 128, 285-292.

S.L. Clement, M. Cristofaro, S.E. Cowgill, and S. Weigand (1999). Germplasm resources, insect resistance, and grain legume improvement. In: Clement, S.L. and Quisenberry, S.S. (eds.), Global plant genetic resources for insect resistant crops, pp. 131-148. CRC Press, Boca Raton, FL.

S.L. Clement, N. Sharaf El-Din, S. Weigand, and S.S. Lateef (1994). Research achievements in plant resistance to insect pests of cool season food legumes. Euphytica 73, 41-50.

S.L. Clement, H.C. Sharma, F.J. Muehlbauer, L.R. Elberson, D.S. Mattinson, and J.K. Fellman (2008). Resistant to beet armyworm in recombinant inbred line population. J Appl Entomol DOI: $10.1111 /$ j.1439-0418.2009.01411.x.

S.L. Clement, J.A. Wightman, D.C. Hardie, P. Bailey, G. Baker, and G. McDonald (2000). Opportunities for integrated management of insect pests of grain legumes. In: R. Knight, (ed.), Linking research and marketing opportunities for pulses in the 21st century, pp. 467-480. Kluwer Academic, Dordrecht. 
S.S. Dahiya, Y.S. Chauhan, C. Johansen, and T.G. Shanower (1999). Adjusting pigeonpea sowing time to manage pod borer infestation. Int Chickpea Pigeonpea Newsl 6, 44-45.

J.C. Daly, J.H. Fisk, and N.W. Forrester (1988). Selective mortality in field trials between strains of Heliothis armigera (Hubner) (Lepidoptera: Noctuidae) resistant and susceptible to synthetic pyrethroids: Functional dominance of resistance and age-class. J Econ Entomol 81, 1000-1007.

S.B. Das (1998). Impact of intercropping on Helicoverpa armigera (Hub.): Incidence and crop yield of chickpea in West Nimar Valley of Madhya Pradesh. Insect Environ 4, 84-85.

S.B. Das and V.P. Kataria (1999). Relative susceptibility of chickpea genotypes against Helicoverpa armigera (Hubner). Insect Environ 5, 68-69.

R.B. Deshmukh, L.B. Mhase, R.P. Aher, N.J. Bendre, and T.B. Kolte (1996a). High-yielding, wiltresistant chickpea cultivar Vijay for central zone of India. Int Chickpea Pigeonpea Newsl 3, $15-17$.

R.B. Deshmukh, L.B. Mhase, R.P. Aher, N.J. Bendre, and T.B. Kolte (1996b). Vishal - A bold-seeded, wilt-resistant, high-yielding chickpea variety for western Maharashtra, India. Int Chickpea Pigeonpea Newsl 3, 14-15.

G.S. Dhaliwal and R. Arora (1994). Trends in agricultural insect pest management. Commonwealth Publishers, New Delhi.

C. Durairaj and A.R. Muthiah 2003. Evaluation of plant oils against pulse beetle in mungbean. Proceedings of the National Symposium on Pulses for Crop Diversification and Natural Resource Management, 20-22 December 2003, P. 246. Indian Institute of Pulses Research (IIPR), Kanpur, Uttar Pradesh.

O.R. Edwards, T.J. Ridsdill-Smith, and F.A. Berlandier (2003). Aphids do not avoid resistance in Australian lupin (Lupinus angustifolius, L. luteus) varieties. Bull Entomol Res 93, 403-411.

W. Erskine, M. Tufail, M.C. Russell, M.M. Rahman, and M.C. Saxena (1994). Current and future strategies in breeding lentil for resistance to biotic and abiotic stresses. Euphytica 73, 127-135.

G.P. Fitt (1989). The ecology of Heliothis species in relation to agroecosystems. Annu Rev Entomol $34,17-52$.

G.P. Fitt and S.C. Cotter (2005). The Helicoverpa problem in Australia: Biology and management. In: Sharma, H.C. (ed.), Heliothis/Helicoverpa management: Emerging trends and strategies for future research, pp. 45-61. Oxford and IBH, New Delhi.

Food and Agriculture Organization (FAO) (2008). FAO statistical yearbook 2007-08. Food and Agriculture Organization, Rome.

S.V.S. Gopalaswamy, H.C. Sharma, G.V. Subbaratnam, and K.K. Sharma (2008). Field evaluation of transgenic pigeonpea plants for resistance to Helicoverpa armigera. Indian J Plant Protect $36,228-234$.

M.P. Goyal, B.B. Kabaria, B.T. Jose, and V.I. Patel (1990). Economic threshold of Helicoverpa pod damage in pigeonpea. Int Pigeonpea Newsl 11, 23-24.

R.V. Gunning, G.D. Moores, and A.L. Devonshire (1996). Esterases and fenvalerate resistance in a field population in Australian Helicoverpa armigera Hubner (Lepidoptera: Noctuidae). Pestic Biochem Physiol 54, 12-23.

R. Hegde and S. Lingappa (1996). Effect of intercropping on incidence and damage by Helicoverpa armigera in pigeonpea. Karnataka J Agric Sci 9, 616-621.

J. Horne and P. Bailey (1991). Bruchus pisorum L. (Coleoptera: Bruchidae) control by knockdown pyrethroid in field peas. Crop Protect 10, 53-56.

International Crops Research Institute for the Semi-Arid Tropics (ICRISAT) (1992). The medium term plan. International Crops Research Institute for the Semi-Arid Tropics (ICRISAT), Patancheru, Andhra Pradesh.

IPCC (Intergovernmental Panel on Climate Change) (2007). Climate change: The physical science basis. In: S. Solomon, D. Qin, M. Manning, Z. Chen, M. Marquis, K. Averyt, and H.L. Miller (eds.), Contribution of Working Group I to the Fourth Assessment Report of the Intergovernmental Panel on Climate Change, 996 pp. Cambridge University Press, Cambridge and New York. 
L.E.N. Jackai (1990). Screening of cowpeas for resistance to Clavigralla tomentosicollis Stal. (Hemiptera: Coreidae). J Econ Entomol 83, 300-305.

I. Javaid, R.B. Dodson, F.M. Hashem, J.M. Joshi, and A.L. Allen (2005). Effect of insecticide spray applications, sowing dates and cultivar resistance on insect pests of cowpea in the Delmarva region of United States. J Sust Agric 26, 57-68.

A.N. Jha (2002). Response to chickpea cultivars of Callosobruchus chinensis. Indian J Entomol 64, 434-437.

A. Kaga and M. Ishimoto (1998). Genetic localization of a bruchid resistance gene and its relationship to insecticidal cyclopeptide alkaloids, the vignatic acids in mungbean (Vigna radiata L. Wilczek). Mol Gen Genet 258, 378-384.

G.B. Kalariya, G.S. Judal, and G.M. Patel (1998). Reaction of pigeonpea genotypes against important insect pests. Gujarat Agric Univ Res J 23, 33-38.

S. Kar, D. Basu, S. Das, N.A. Ramkrishnan, P. Mukherjee, P. Nayak, and S.K. Sen (1997). Expression of CryIA(c) gene of Bacillus thuringiensis in transgenic chickpea plants inhibits development of pod borer (Heliothis armigera) larvae. Transgenic Res 6, 177-185.

N. Kaya and P. Hincal, (1987). Population fluctuations and damage by the lentil leaf weevil (Sitona crinitus Herbst.) (Coleoptera: Curculionidae) in Denizli. Turkiye 1. Entomoloji KongresiIzmir, Ege Universitesi, Turkey. pp. 259-266.

S.U. Khattak, G.Z. Afridi, A.U. Khan, A.F. Alamzeb, and S.K. Khalil (2001). Screening of different chickpea cultivars for resistance against pulse beetle Callosobruchus maculatus (F.). Proc Pak Congr Zool 21, 95-100.

A.D. Khurana (1997). Seasonal activity and chemical control of Helicoverpa armigera (Hubner) on chickpea. J Insect Sci 10, 48-51.

A.B.S. King (1994). Heliothis/Helicoverpa (Lepidoptera: Noctuidae). In: G.A. Matthews, J.P. Tunstall (eds.), Insect pests of cotton, pp. 39-106. CAB International, Wallingford.

E.G. King, A. Baumhover, L.F. Bouse, P. Greany, A.W. Hartstack, K.R. Hooper, E.F. Knipling, R.K. Morrison, W.C. Nettles, and J.E. Powell (1986). Augmentation of entomophagous arthropods. In: Johnson, S.J., King, E.G., and Bradley, J.R., (eds.), Theory and tactics of Heliothis population management. 1. Cultural and biological control, pp. 116-131. Southern Cooperative Series Bulletin 316.

K.R. Kranthi, D.R. Jadhav, S. Kranthi, R.R. Wanjari, S. Ali, and D.A. Russell (2002). Insecticide resistance in five major insect pests of cotton in India. Crop Protect 21, 449-460.

M. Kumar and R. Singh (2002). Potential of Pongamia glabra Vent. as an insecticide of plant origin. Biol Agric Hortic 20, 29-50.

S. Lakshminarayana and D.S. Misra (1992). Management of yellow mosaic virus through whitefly (Bemisia tabaci) resistant green gram varieties. National Seminar on Changing Scenario in Pests and Pest Management in India, 31 January-2 February 1992. Plant Protection Association of India, Rajendarnagar, Hyderabad.

S.S. Lal (1987). Insect pests of mung, urid, cowpea and pea and their management. In: Veerabhadra Rao, M., Sithanantham, S. (eds.), Plant protection in field crops, pp. 185-202. Plant Protection Association of India, Hyderabad, Andhra Pradesh.

C.J. Lambrides and B.C. Imrie (2000). Susceptibility of mungbean varieties to the bruchid species Callosobruchus maculatus (F.), C. phaseoli (Gyll.), C. chinensis (L.), and Acanthoscelides obtectus (Say.) (Coleoptera: Chrysomelidae). Aust J Agric Res 51, 85-89.

S.S. Lateef (1985). Gram pod borer (Heliothis armigera) (Hub.) resistance in chickpea. Agric Ecosyst Environ 14, 95-102.

S.S. Lateef and M.P. Pimbert (1990). The search for host plant resistance of Helicoverpa armigera in chickpea and pigeonpea at ICRISAT. Proceedings of the Consultative Group Meeting on the Host Selection Behavior of Helicoverpa armigera, 5-7 March 1990, pp. 14-18. International Crops Research Institute for the Semi-Arid Tropics, Patancheru, Andhra Pradesh.

S.S. Lateef and J.N. Sachan 1990. Host plant resistance to Helicoverpa armigera (Hub.) in different agro-economical conditions. Chickpea in Nineties: Proceedings of the Second International 
Workshop on Chickpea, 4-8 December 1989, pp. 181-189. International Crops Research Institute for the Semi-Arid Tropics, Patancheru, Andhra Pradesh.

H.J. Lawlor, K.H.M. Siddique, R.H. Sedgley, and N. Thurling (1998). Improving cold tolerance and insect resistance in chickpea and the use of AFLPs for the identification of molecular markers for these traits. Acta Hortic 461, 185-192.

A. Liu and T.J. Ridsdill-Smith (2001). Comparison of feeding damage by redlegged earth mite (Halotydeus destructor (Tucker)) to different grain legume species. In: Halliday, R.B., Walter, D.H., Proctor, H.C., Norton, R.A., and Colloff, M.J. (eds.), Acarology: Proceedings of the 10th International Congress, pp. 295-299. CSIRO Publishing, Melbourne.

Loss, S., N. Brandon, and K.H.M. Siddique (eds.) (1998). The chickpea book. Bulletin 1326. Western Australian Department of Agriculture, Perth, 76 pp.

G.K. Mahapatro and G.P. Gupta (1999). Evenings suitable for spraying Bt formulations. Insect Environ 5, 126-127.

G.A. Maiteki and R.J. Lamb (1985). Spray timing and economic threshold for the pea aphid Acyrthosiphon pisum (Homoptera: Aphididae), on field peas in Manitoba. J Econ Entomol 78, 1449-1454.

G.T. McIntyre and R.J. Titmarsh (1989). Software for Primary Producers. V1.0 Agdex 168.614. Queensland Department of Primary Industry, Brisbane, Queensland.

K.S. Meenakshisundaram and G.T. Gujar (1998). Correlation and larval population of Heliothis armigera with yield parameters of pigeonpea (Cajanus cajan). Indian J Agric Sci 68, 198-200.

F.J. Messina and J.A.A. Renwick (1985). Resistance of Callosobruchus maculatus (Coleoptera: Bruchidae) in selected cowpea lines. Environ Entomol 14, 868-872.

P.J. Michael, S.S. Dhalival, and G.P. Mangano (1990). Experimenting with chemical control of the adult pea weevil, Bruchus pisorum (L.), on field pea crops. In: Smith, A.M. (ed.), Workshop Proceedings: National Pea Weevil Workshop, pp. 34-40. Victoria Department of Agriculture and Rural Affairs, Melbourne.

G. Mohammed and A.S. Rao (1999). Evaluation of some new insecticides on Helicoverpa armigera (Hubner) in pigeonpea. Int Chickpea Pigeonpea Newsl 6, 46-47.

S. Mohan and P. Fields (2002). A simple technique to assess compounds that are repellant (or) attractive to stored product insects. J Stored Prod Res 38, 23-31.

R.L. Morton, H.E. Schroeder, K.S. Bateman, M.J. Chrispeels, E. Armstrong, and T.J.V. Higgins (2000). Bean $\alpha$-amylase inhibitor I in transgenic peas (Pisum sativum) provides complete protection from pea weevil (Bruchus pisorum) under field conditions. Proc Natl Acad Sci USA 97, 3820-3825.

L.L. Murdock and R.E. Shade (1991). Eradication of cowpea weevil infestations in cowpea by solar heating. Am Entomol 37, 228-231.

D.A.H. Murray and M.P. Zalucki (1990). Survival of Helicoverpa punctigera (Wallengren) and H. armigera (Hubner) (Lepidoptera: Noctuidae) pupae submerged in water. J Aust Entomol Soc 29, 91-192.

J.D. Murray, T.E. Michaels, C. Cardona, A.W. Schaafsma and K.P. Pauls (2004). Quantitative trait loci for leafhopper (Empoasca fabae and Empoasca kraemeri) resistance and seed weight in the common bean. Pl Breed 123: 474-479.

G.O. Myers, C.A. Fatokun, and N.D. Young (1996). RFLP mapping of an aphid resistance gene in cowpea (Vigna unguiculata (L.) Walp.). Euphytica 91, 181-187.

J.S. Naresh and V.S. Malik (1986). Observations on the insect pests of chickpea (Cicer arietinum L.) in Haryana. Bull Entomol 27, 75-77.

B.S. Nielsen (1990). Yield response of Vicia faba in relation to infestation levels of Sitona lineatus L. (Col., Curculionidae). J Appl Entomol 110, 398-407.

S. Oghiakhe, L.E.N. Jackai, and W.A. Makanjuola (1992). A rapid visual field screening technique for resistance of cowpea (Vigna unguiculata) to the legume pod borer, Maruca testulalis (Lepidoptera: Pyralidae). Bull Entomol Res 82, 507-512.

L.E. O'Keeffe, H.W. Homan, and D.J. Schotzko (1991). The pea leaf weevil. Current Information Series No. 883. University of Idaho, College of Agriculture, Moscow. 
S.K. Parsai (1996). Studies on pod fly and pod borer damage in certain medium/late maturing varieties of pigeonpea. Bhartiya Krishi Anusandhan Patrika 11, 117-120.

C.S. Pawar, V.S. Bhatnagar, and D.R. Jadhav (1986). Heliothis species and their natural enemies, with their potential for biological control, pp. 116-131. Proc Indian Acad Sci (Anim Sci) 95, 695-703.

E.O. Pearson (1958). The insect pests of cotton in tropical Africa. CAB International, Wallingford.

J.C. Popelka, N. Terryn, and T.J. Higgins (2004). Gene technology for grain legumes: Can it contribute to the food challenge in developing countries? Plant Sci 167, 195-206.

S. Ramarethinam, S. Marimuthu, B. Rajagopal, and N.V. Murugesan (1998). Relative changes in the virulence and infectivity of the nuclear polyhedrosis virus in relation to the dietary habit of Helicoverpa armigera (Hubner) (Lep., Noctuidae). J Appl Entomol 122, 623-628.

G.V. Ranga Rao, M.S. Chari, C.S. Pawar, O.P. Sharma, and V. Rameshwar Rao (2005). Helicoverpa management: Successes and failures - Lessons for the future. In: Sharma, H.C., (ed.), Heliothis/Helicoverpa management: Emerging trends and strategies for future research, pp. 431-452. Oxford and IBH, New Delhi.

M.A. Ravindra 1999. Studies on the evaluation and control of field infestation of pulse beetle, Callosobruchus chinensis (Linn.) (Bruchidae: Coleoptera). M.Sc. Agri. Thesis. University of Agricultural Sciences, Hebbal, Bangalore, Karnataka.

V.S. Reddy, T.R. Babu, S.H. Hussaini, and B.M. Reddy (1996). Effect of edible and non-edible oils on the development of pulse beetle, Collasobruchus chinensis L. and on viability of mungbean seeds. Pest Manage Econ Zool 2, 15-17.

W. Reed, C. Cardona, S. Sithanantham, and S.S. Lateef (1987). The chickpea insect pests and their control. In: Saxena, M.C., Singh, K.B. (eds.), The chickpea, pp. 283-318. CAB International, Wallingford.

D. Rees (2004). Insects of stored products. CSIRO Publishing, Canberra.

H. Rembold and H. Tober (1985). Kairomones as pigeonpea resistance factors against Heliothis armigera. Insect Sci Appl 6, 249-252.

H. Rembold, P. Wallner, A. Kohne, S.S. Lateef, M. Grune, and C.H. Weigner (1990). Mechanism of host plant resistance with special emphasis on biochemical factors. Chickpea in the Nineties: Proceedings of the Second International Workshop on Chickpea Improvement, 4-8 December 1989, pp. 191-194. International Crops Research Institute for the Semi-Arid Tropics, Patancheru, Andhra Pradesh/International Center for Agricultural Research in the Dry Areas, Alleppo, Syria.

A. Riaz, M. Aslam, and N. Suleman (2000). Evaluation of resistance in different chickpea strains to Callosobruchus chinensis (Linn.) under laboratory conditions. Pak J Biol Sci 3(6), 1033-1036.

R.L. Ridgeway, E.G. King, and J.L. Carillo (1977). Augmentation of natural enemies for control of plant pests in the Western Hemisphere. In: Ridgeway, R.L., and Vinson, S.B., (eds.), Biological control by augmentation of natural enemies, pp. 379-416. Plenum Press, New York.

T.J. Ridsdill-Smith (1997). Biology and control of Halotydeus destructor (Penthaleidae: Acarina): A review. Exp Appl Acarol 21, 195-224.

J. Romeis and T.G. Shanower (1996). Arthropod natural enemies of Helicoverpa armigera (Hübner) (Lepidoptera: Noctuidae) in India. Biocontrol Sci Technol 6, 481-508.

C. Rosenzweig and D. Liverman (1992). Predicted effects of climate change on agriculture: A comparison of temperate and tropical regions. In: Majumdar, S.K., (ed.), Global climate change: Implications, challenges, and mitigation measures, pp. 342-361. The Pennsylvania Academy of Sciences, USDA, Easton, PA.

D.R. Rummel and K.C. Neece (1989). Winter survival of Heliothis zea (Boddie) in cultivated soil in the southern Texas High Plains. Southwest Entomol 14, 117-125.

F.M. Said (2004). A wonder tree. Rev Dawn 8, 26-27.

B.K. Sarmah, A. Moore, W. Tate, L. Molvig, R.L. Morton, D.P. Rees, P. Chiaiese, M.J. Chrispeels, L.M. Tabe, and T.J. Higgins (2004). Transgenic chickpea seeds expressing high levels of amylase inhibitor. Mol Breed 14, 73-82. 
R.M. Sawicki and I. Denholm (1987). Management of resistance to pesticides in cotton pests. Trop Pest Manage 33, 262-272.

H. Saxena and R. Ahmad (1997). Field evaluation of Beauveria bassiana (Balsamo) Vuillemin against Helicoverpa armigera (Hubner) infecting chickpea. J Biol Control 11, 93-96.

A.V. Schoonhoven and C. Cardona (1986). Main insect pests of stored beans and their control. Study guide. Centre International de Agriculture Tropical (CIAT), Cali, Columbia.

D.J. Schotzko and L.E. O'Keeffe (1989). Comparison of sweep net, D-vac, and absolute sampling, and diel variation of sweep net sampling estimates in lentils for pea aphid (Homoptera: Aphididae), nabids (Hemiptera: Nabidae), lady beetles (Coleoptera: Coccinellidae), and lacewings (Neuroptera: Chrysopidae). J Econ Entomol 82, 491-506.

H.E. Schroeder, S. Gollasch, A. Moore, L.M. Tabe, S. Craig, D.C. Hardie, M.J. Chrispeels, D. Spencer, and T.J.V. Higgins (1995). Bean alpha-amylase inhibitor confers resistance to pea weevil (Bruchus pisorum) in transgenic peas (Pisum sativum L.). Plant Physiol 107, $1233-1239$.

R.E. Shade, H.E. Schroeder, J.J. Pueyo, L.M. Tabe, L.L. Murdock, T.J.V. Higgins, and M.J. Chrispeels (1994). Transgenic pea seeds expressing $\alpha$-amylase inhibitor of the common bean are resistant to bruchid beetles. Bio Technol 12, 793-796.

H.C. Sharma (2001). Crop protection compendium: Helicoverpa armigera. Electronic compendium for crop protection. CAB International, Wallingford, $72 \mathrm{pp}$.

Sharma, H.C. (ed.) (2005). Heliothis/Helicoverpa management: Emerging trends and strategies for future research. Oxford and IBH, New Delhi, $469 \mathrm{pp}$.

H.C. Sharma (2009). Applications of biotechnology in pest management and ecological sustainability. CRC Press, Taylor and Francis, Boca Raton, FL, 526 pp.

H.C. Sharma, R. Ahmad, R. Ujagir, R.P. Yadav, R. Singh, and T.J. Ridsdill-Smith (2005). Host plant resistance to cotton bollworm/legume pod borer, Heliothis/Helicoverpa. In: Sharma, H.C. (ed.), Heliothis/Helicoverpa management: Emerging trends and strategies for future research, pp. 167-208. Oxford and IBH, New Delhi.

H.C. Sharma, S.L. Clement, T.J. Ridsdill-Smith, G.V. Ranga Rao, M. El Bouhssini, R. Ujagir, C.P. Srivastava, and M. Miles (2008). Insect pest management in food legumes: The future strategies. In: Kharkwal M.C. (ed.), Food legumes for nutritional security and sustainable agriculture, Proceedings of the IVth International Food Legumes Research Conference, Vol. 1, pp. 522-544. Indian Society of Genetics and Plant Breeding, New Delhi, India.

H.C. Sharma, J.H. Crouch, K.K. Sharma, N. Seetharama, and C.T. Hash (2002). Applications of biotechnology for crop improvement: Prospects and constraints. Plant Sci 163, 381-395.

H.C. Sharma and R. Ortiz (2002). Host plant resistance to insects: An eco-friendly approach for pest management and environment conservation. J Environ Biol 23, 11-35.

H.C. Sharma and G. Pampapathy (2004). Effect of natural plant products, brassinolide, and host plant resistance in combination with insecticides on pod borer, Helicoverpa armigera (Hubner) damage in pigeonpea, Cajanus cajan (L.) Millsp. Indian J Plant Prot 32, 40-44.

H.C. Sharma, V. Rajeev, P.M. Gaur, and C.L.L. Gowda (2008). Potential for using morphological, biochemical, and molecular markers for resistance to insect pests in grain legumes. J Food Legumes 21, 211-217.

H.C. Sharma, K.B. Saxena, and V.R. Bhagwat (1999). Legume pod borer, Maruca vitrata: Bionomics and management. Information Bulletin 55. International Crops Research Institute for the Semi-Arid Tropics (ICRISAT), Patancheru, Andhra Pradesh, $35 \mathrm{pp}$.

H.C. Sharma, K.K. Sharma, and J.H. Crouch (2004). Genetic engineering of crops for insect control: Effectiveness and strategies for gene deployment. CRC Crit Rev Plant Sci 23, 47-72.

S.R. Singh (1978). Resistance to pests of cowpea in Nigeria. In: Singh, S.R., van Emden, H.F., and Taylor, J.A., (eds.), Pests of grain legumes: Ecology and control, pp. 267-279. Academic Press, London.

J.P. Singh and G.P. Gupta (1997). Evolution of effective and economical spray schedules based on spray initiation against bollworm complex in cotton. Pest Res $J$ 9, 175-184. 
S.R. Singh and L.E.N. Jackai (1985). Insect pests of cowpea in Africa: Their life cycle, economic importance, and potential for control. In: Singh, S.R., Rachie, K.O. (eds.), Cowpea research, production and utilization, pp. 217-231. John Wiley and Sons, Chichester.

D. Singh and S. Mehta (1998). Screening of plant materials for repellant and insecticidal properties against pulse beetle (Callosobruchus chinensis) and housefly (Musca domestica). J Med Aromat Plant Sci 20(2), 397-400.

S.K. Singh, V. Sharma, Y.S. Rathore, and C.P. Yadav 2003. Effectiveness of edible and non-edible oils against bruchid infesting pigeonpea. Proceedings, National Symposium on Pulses for Crop Diversification and Natural Resource Management, 20-22 December 2003, pp. 226. Indian Institute of Pulses Research (IIPR), Uttar Pradesh, Kanpur.

K.B. Singh and S. Weigand (1996). Registration of three chickpea leaf miner resistant lines: ILC 3800, ILC 5901, and ILC 7738. Crop Sci 36, 472.

A.M. Smith and G. Hepworth (1992). Sampling statistics and a sampling plan for eggs of pea weevil (Coleoptera: Bruchidae). J Econ Entomol 85, 1791-1796.

J.J. Soroka and P.A. Mackay (1990). Seasonal occurrence of the pea aphid, Acyrthosiphon pisum (Harris) (Homoptera: Aphididae), on cultivars of field peas in Manitoba and its effects on pea growth and yield. Can Entomol 122, 503-513.

S. Subramanya, B. Ranganna, and B.S. Bisht (1999). Post harvest management of pulse beetle: A review of research post harvest technology scheme. University of Agricultural Sciences, Bangalore, Karnataka, 82 pp.

B. Taran, T.E. Michaels, and K.P. Pauls (2002). Genetic mapping of agronomic traits in common bean (Phaseolus vulgaris L.). Crop Sci 42, 544-446.

D.J. Thackray, T.J. Ridsdill-Smith, and D.J. Gillespie (1997). Susceptibility of grain legumes to redlegged earth mite (Halotydeus destructor Tucker) damage at seedling stage. Plant Protect $Q 12,141-144$.

T.T. Thu, T.T.X. Mai, E. Dewaele, S. Farsi, Y. Tadesse, G. Angenon, and M. Jacobs (2003). In vitro regeneration and transformation of pigeonpea [Cajanus cajan (L.) Millsp]. Mol Breed 11, $159-168$.

T.P. Trivedi, C.P. Yadav, C.P. Vishwadhar, C.P. Srivastava, A. Dhandapani, D.K. Das, and J. Singh (2005). Monitoring and forecasting of Heliothis/Helicoverpa populations. In: Sharma, H.C. (ed.), Heliothis/Helicoverpa management: Emerging trends and strategies for future research, pp. 119-140. Oxford and IBH, New Delhi.

H. van den Berg, J.K. Waage, and M.J.W. Cock (1988). Natural enemies of Helicoverpa armigera in Africa - A review. Commonwealth Agricultural Bureaux, International Institute of Biological Control, Ascot, Berks, PA, $81 \mathrm{pp}$.

H.F. van Emden, S.L. Ball, and M.R. Rao (1988). Pest and disease problems in pea, lentil, faba bean, and chickpea. In: Summerfield, R.J. (ed.), World crops: Cool season food legumes, pp. 519-534. Kluwer Academic, Dordrecht.

J.M. Villareal, D.M. Hautea, and A.L. Carpena (1998). Molecular mapping of the bruchid resistance gene in mungbean Vigna radiata L. Phil J Crop Sci 23(Suppl. 1), 1-9.

A. Ward and S. Morse (1995). Partial application of insecticide to broad bean (Vicia faba) as a means of controlling bean aphid (Aphis fabae) and bean weevil (Sitona lineatus). Ann Appl Biol 17, 239-249.

S. Weigand, S.S. Lateef, N. Sharaf El-Din, S.F. Mahmoud, K. Ahmed, and K. Ali (1994). Integrated control of insect pests of cool season food legumes. In: Muehlbauer, F.J., and Kaiser, W.J. (eds.), Expanding the production and use of cool season food legumes, pp. 679-694. Kluwer Academic, Dordrecht.

S. Weigand and M.P. Pimbert (1993). Screening and selection criteria for insect resistance in coolseason food legumes. In: K.B. Singh, M.C. Saxena, (eds.), Breeding for stress tolerance in cool season food legumes, pp. 145-156. John Wiley and Sons, London.

J.A. Wightman, M.M. Anders, V. Rameshwar Rao, and L. Mohan Reddy (1995). Management of Helicoverpa armigera (Lepidoptera: Noctuidae) on chickpea in southern India: Thresholds and the economics of host plant resistance and insecticide application. Crop Protect 14, 37-46. 
D.R. Wilkin and A.A. Green (1970). Polythene sacks for the control of insects in bagged grain. J Stored Prod Res 6, 97-101.

T.J. Yang, D.H. Kim, G.C. Kuo, L. Kumar, N.D. Yong, and H.G. Park (1998). RFLP markerassisted selection in backcross breeding for introgression of the bruchid resistance gene in mungbean. Korean J Breed 30, 8-15.

N.D. Young, L. Kumar, D. Menancio-Hautea, D. Danesh, N.S. Talekar, S. Shanmugasundarum, and D.H. Kim (1992). RFLP mapping of a major bruchid resistance gene in mungbean (Vigna radiata, L. Wilczek). Theor Appl Genet 84, 839-844.

M.P. Zalucki, G. Daglish, S. Firempong, and P. Twine (1986). The biology and ecology of Heliothis armigera (Hubner) and $H$. punctigera Wallengren (Lepidoptera: Noctuidae) in Australia: What do we know? Aust J Zool 34, 779-814.

W. Zehrer (1980). Traditional methods of insect pest control in stored grains. Post harvest problems. Documentation of OAU/GTZ Seminar. Schriffenreihe No. 115. German Society for Technical Cooperation (GTZ), Eschborn, Germany. pp. 98-129. 